\title{
Climate change: Double-edged sword for African trade and development
}

\author{
Godwell Nhamo \\ University of South Africa \\ nhamog@unisa.ac.za
}

\begin{abstract}
African governments face increasing pressure from major export destinations, primarily former colonial and slave-owning countries, to be climate change compliant. This will certainly be on display at the upcoming December 2009 United Nations Climate Change Conference in Copenhagen, which will seek to strengthen climate change rules agreed on in Kyoto, Japan, in 1997, and adopt new protocols on global climate change regulation. Climate change is a double-edged sword: on one side it is hitting Africa's agricultural sector with increased droughts, floods, extreme frost and wildfires; and on the other, African governments are being forced to respond to stringent regulatory regimes imposed by international export destinations. Currently, the per capita greenhouse gas emissions from the highly industrialised nations - the North - is estimated to be four times that of Africa and the rest of the developing world. Twin research questions were investigated in this article: (1) to what extent does climate change impact on African trade and development, and (2) how can African governments stay on a path of sustained trade and development in this era of climate change? The article argues that Africa's survival in these times of climate change compliance rests on a shift to greater intra-African trade, as individual nations move towards cleaner and more organic technologies to become full-fledged partners in the international climate change regulatory regime.
\end{abstract}

Keywords: Africa; carbon emission; carbon footprint; carbon market; climate change; development; food miles; fossil fuel; global warming; greenhouse gases; international trade; intra-African trade; Kyoto Protocol; regulatory regimes; United Nations Framework Convention on Climate Change (UNFCCC) 


\section{Introduction}

The climate of the world varies from one decade to the next, and a changing climate is natural, continuous and expected. Energy from the sun drives the global climate system. Gases in the earth's atmosphere, which trap this energy and thus warm the earth, are called greenhouse gases (GHGs) and the process is known as the greenhouse effect. Without this, there would be no life on earth. However, since the late $19^{\text {th }}$ century scientists have hypothesised that industrial-age coal burning, combined with the clearing of forests, has resulted in an increased concentration of GHGs in the atmosphere. This, say scientists, is likely to lead to more solar radiation being trapped, which in turn will lead to the earth's surface warming up. This is known as the enhanced greenhouse effect, and the potential impact can be catastrophic. In the first United Nations conference on the environment, convened in 1972, climate change (CC) hardly registered on the agenda. It was not until 1988 that the Intergovernmental Panel on Climate Change (IPCC) was formed to collate and assess evidence on CC. In its Second Assessment Report in 1995, the IPCC concluded that the balance of evidence suggested 'a discernible human influence' on the earth's climate. By 2007, the IPCC had concluded that it is more than 90 per cent likely that humanity's emissions of GHGs are responsible for modern-day accelerated CC (IPCC 2007).

Countering global warming, which leads to climate change, remains the critical challenge of this generation (Kolk and Pinkse 2009, 1). International trade, within the confines of $\mathrm{CC}$, is prominently on the agenda of the $21^{\text {st }}$ century. The debate has moved squarely from the realm of science to that of the economy (Arckerman 2009, vii). After ratification of the Kyoto Protocol (KP) and its market-based cooperation mechanisms in 2005, African governments must be cautious as they push to expand trade and strengthen their economies. When the trading activities of a nation expand there is undoubtedly a consequential effect on the environment.

A conceptual framework has been developed for examining how trade opening can affect the level of GHG emissions. The impact is divided into three independent effects, namely scale, composition and technique (WTO-UNEP 2009, 49-52):

- The scale effect refers to the impact on GHG emissions from the increased output or economic activity resulting from freer trade;

- The composition effect refers to the way that trade liberalisation changes the mix of a country's production towards those products where it has a comparative advantage; the composition effect will result in less GHG emissions only if the expanding sectors are less energy intensive than the contracting sectors; and

- Trade opening can lead to improvements in energy efficiency - the technique effect - so that the production of goods and services generates less GHG emissions; this decline in emission intensity can come about if, for example, freer trade increases the availability and lowers the cost of environmentally friendly goods, services and technologies. ${ }^{1}$ 
Vast investments in alternative energy resources and a call by the highly industrialised developed countries to substitute the combustion engine have gathered global momentum: Africa must respond. Yet most countries in Africa do not have the financial and technical resources to address this challenge. Addressing CC can have an effect on the pattern and volume of international trade flows and also has the potential to alter the comparative trade advantage of countries. This can lead to shifts in the trading patterns of African governments.

This article exposes how governments from major export destinations, including Europe and the United States (US), are putting stringent CC policy regimes in place, making it more and more difficult for African goods and services from so-called 'dirty' energy-intense industries to penetrate those markets. Indeed, Africa's strategic resources - gold, so-called 'dirty' coal, petroleum, platinum, diamonds, chrome and uranium, which are critical to the continent's sustainable growth - are precisely the industries that stand to suffer the most under harsh CC regulatory regimes in export destinations. What should Africa do with all the coal and petroleum reserves in its soil? How can they be exploited to benefit its people, while not inflicting greater damage on the earth's atmosphere? African governments are on notice; they must be proactive and must engage the CC mitigation and adaptation space. They must responsibly address $\mathrm{CC}$ together with the rest of the world, from a common but differentiated responsibility perspective. African governments must join voices to advocate and lobby for fair treatment in the $\mathrm{CC}$ discourse. Recent sentiments emanating from the African Union (AU) suggest that the Copenhagen summit will be a forum for such advocacy.

\section{Research questions and methodology}

Twin research questions are addressed in this article: (1) to what extent does $\mathrm{CC}$ impact on African trade and development, and (2) how can African governments collectively and individually remain on a sustained trade and developmental path in this era of CC? The article uses secondary data, provides a literature review, and draws from an audit of CC legislation both at the global level and in selected African export destinations. Secondary trade data were retrieved from the United Nations Conference on Trade and Development (UNCTAD) database. These data were specifically for exports between 2004 and 2006. Other data on carbon emissions were also gathered, with special focus on Africa as a trading block or area.

\section{Understanding climate change}

Before tackling the subject of $\mathrm{CC}$ it is important to understand the link between the socio-economic system and natural environment cycles. This offers insight into how we relate to the environmental load (Moriguchi 2006); that is, societal interactions with the natural environment cycle through the extraction of resources, emissions and the generation of waste, and the manner in which this occurs in the context of global warming and $\mathrm{CC}$. The socio-economic cycle system is mainly built around production, 
distribution and consumption. The natural environment cycle comprises the atmosphere, water and soil - together they form the ecosystems web of interaction. Among other activities, the environmental load results in human-induced GHGs which contribute to global warming and $\mathrm{CC}$. Carbon dioxide $\left(\mathrm{CO}_{2}\right)$, methane $\left(\mathrm{CH}_{4}\right)$ and nitrous oxide $\left(\mathrm{N}_{2} \mathrm{O}\right)$ are among the chief-known GHGs. In terms of everyday usage, these and other GHG emissions are converted to their carbon dioxide equivalence (denoted as $\mathrm{CO}_{2} \mathrm{e}$ ), based on what is termed 'global warming potential' (GWP).

All GHGs have a GWP. The GWP is an index that compares different GHGs to carbon dioxide (IUCN 2004), hence it is an indicator of how much a specific mass of GHG is predicted to contribute to global warming, as denominated to carbon dioxide. GWP therefore tallies a particular GHG to the same measure of carbon dioxide. For those gases with a high global warming potential, a relatively small emission can have a considerable impact. The GWP of selected GHGs are: carbon dioxide (1 GWP - base measurement unit); methane (GWP of $\left.23 \mathrm{CO}_{2} \mathrm{e}\right)$; nitrous oxide $\left(\mathrm{GWP}\right.$ of $296 \mathrm{CO}_{2} \mathrm{e}$ ); perfluorocarbons (GWP of between 4,800 to $9,200 \mathrm{CO}_{2} \mathrm{e}$ ); hydrofluorocabons (GWP of between 12,000 to 12,000 $\mathrm{CO}_{2} \mathrm{e}$ ); and sulphur hexafluoride ( $\mathrm{GWP}$ of 22,200 $\mathrm{CO}_{2} \mathrm{e}$ ) (IUCN 2004).

According to the Intergovernmental Panel on Climate Change (IPCC) Working Group II 2007 Report, the key sources of GHGs are: waste and wastewater (3\%); residential and commercial activities (8\%); transport (13\%); agriculture (14\%); deforestation (17\%); industry (19\%); and energy supply (26\%) (FAO 2008, 1). The energy supply and industry sectors contribute, by far, the largest share of GHGs with a combined total of 45 per cent. Agriculture also takes up a significant portion. Article II of the UNFCCC (1992) outlines the need to ensure the stabilisation of GHG concentrations in the atmosphere at a level that would prevent dangerous anthropogenic interference with the climate system. Such a level 'should be achieved within a timeframe sufficient to allow ecosystems to adapt naturally to climate change, to ensure that food production is not threatened and to enable economic development to proceed in a sustainable manner' (FAO 2008, 1).

The greenhouse effect is best illustrated by using the common agricultural greenhouse as an example. In order to maintain a stable and controllable temperature and humidity regime for certain crops (mainly cash crops), farmers construct greenhouses. These structures are built to allow the sun to penetrate through the roof, while maintaining the required temperature and humidity levels needed for good plant growth. The findings of the European Conference of Ministers of Transport (ECMT) (1993) describe the GHG effect in the following scientific terms: the warming of the earth's atmosphere, the greenhouse effect, is due to enhanced absorption of infrared radiation. GHGs are unable to absorb solar radiation in the visible spectrum, and absorb the infra-red radiation from the earth's surface. In this way GHGs change the radiation balance of the earth, then form a film of gases that impedes the reflection of heat, leading to global warming.

There is now overwhelming scientific evidence pointing to ongoing CC (WTOUNEP 2009, vii-viii). The IPCC estimates that during the $20^{\text {th }}$ century, the global 
average surface temperature increased by approximately $0.74^{\circ} \mathrm{C}$. It predicts that global average temperatures will increase by between $1.4^{\circ} \mathrm{C}$ and $6.4^{\circ} \mathrm{C}$ from 1990 and $2100-$ a very significant phenomenon, considering that a $2-3^{\circ} \mathrm{C}$ rise in temperature is usually cited as a threshold limit. Anything greater than that, and it will be impossible to avoid dangerous interference with the global climate system. This warming potential will continue, even if GHG emissions were to cease today. The International Energy Agency (IEA) has indicated that GHG emissions have roughly doubled since the 1970s, and predictions show that GHG emissions will increase by between 25 and 90 per cent in the period 2000-2030 (WTO-UNEP 2009).

Developing nations, and especially the Group of Five (G5) emerging economies of Brazil, China, India, Mexico and South Africa, are viewed as major emerging GHG emitters. But the per capita GHG emissions from the developed North are estimated to be four times that of Africa and other developing nations (WTO-UNEP 2009). Member nations of the Organisation for Economic Co-operation and Development (OECD) are said to be responsible for about 77 per cent of the total historical GHG emissions. A calculation by the World Resources Institute (http://www.wri.org/1-202-729-7600) reveals that Africa's historical carbon dioxide emissions from fossil fuels combustion for the period 1900-1999 stood at a mere 2.5 per cent. This is in sharp contrast to the US's 30.3 per cent, Europe's 27.7 per cent, the former Soviet Union's 13.7 per cent, as well as China, India and Developing Asia's 12.2 per cent. In fact, Africa's share was even less than the 3.7 per cent for Japan. Other figures are 2.3 per cent for Canada, 3.8 per cent for South and Central America, 2.6 per cent for the Middle East and 1.1 per cent for Australia.

Climate Works Foundation (2009) maintains that global GHGs increased from about 38 gigatonnes (Gt) in 1990 to over $45 \mathrm{Gt}$ in 2005. A business-as-usual attitude, coupled with the absence of fundamental policy regimes and technological shifts, is predicted to result in GHG emissions reaching 61Gt by 2020 and 70Gt by 2030 (Climate Works Foundation 2009,6). Current scientific evidence suggests that in order for the world to remain on a 450 part per million scenario - which will give a $40-60 \%$ chance of restricting global warming to $2^{\circ} \mathrm{C}$ above the pre-industrial level - GHG emissions need to peak before 2020 at less than $50 \mathrm{Gt}$, then plateau between 2025 and 2035 and decline sharply thereafter (ibid.).

The IPCC predicts the following phenomena and direction of trend in weather and climate events, much of which impacts negatively on Africa:

- By 2020, between 75 and 250 million people are projected to be affected by water shortages due to $\mathrm{CC}$;

- By 2020, in some countries (especially those in Africa) yields from rain-fed agriculture could be reduced by up to 50 per cent;

- Agricultural production, including access to food, in many African countries is projected to be severely compromised. This would have a further adverse effect on the supply of food and would exacerbate malnutrition; 
- Towards the end of the $21^{\text {st }}$ century, projected sea level rise will affect low-lying coastal areas with large populations and the cost of adaptation could amount to at least 5-10 per cent of gross domestic product (GDP);

- By 2080, an increase of 5 to 8 per cent of arid and semi-arid land in Africa is projected under a range of climate scenarios. (WTO-UNEP 2009, 18)

\section{Climate change and development}

Until the start of the century, $\mathrm{CC}$ was viewed as almost exclusively an environmental issue with limited relevance to development policy makers and/or practitioners. Similarly, within the CC community, development approaches were given little attention as the search for strategies to reduce GHG emissions focused on the natural sciences (Huq, Reid and Murray 2006). It was only in September 2007 that CC was discussed at the $62^{\text {nd }}$ Session of the United Nations' General Assembly in New York, for the first time. Today, no one can seriously deny the correlation between $\mathrm{CC}$ and development. Agriculture, one of the sectors hardest hit by $\mathrm{CC}$, remains the backbone of the economy of many African nations. In some least developed countries, this sector contributes between 30 and 60 per cent to the GDP (Sneddon 2009, 1). This translates to the employment of at least 25 per cent of the population, in addition to representing a key source of international trade, assuring food security and generating other sources of income. In 2007, agricultural exports for Commonwealth countries in the Caribbean comprised 33 per cent of total exports; 14 per cent in South Asia; 35 per cent in Africa; and 53\% in the Pacific (Sneddon 2009, 1-8). Hence any negative CC impact on this sector will significantly impact the growth and development potential of Africa and other developing countries.

Oxfam (2007) estimates that the costs of CC adaptation in developing countries will be well above the World Bank's widely cited estimate of between $\$ 10$ and $\$ 40$ billion annually. Instead, it predicts that at least $\$ 50$ billion will be needed for adaptation initiatives annually - a figure that could increase significantly if GHGs are not cut rapidly, as compelled by available science. In connection with the upcoming Copenhagen climate change conference, Libyan president Muammar Gaddafi (current Chairperson of the African Union) declared that Africa needs $\$ 67$ billion annually from the developed countries to finance its $\mathrm{CC}$ adaptation activities, otherwise there will be no new climate deal at the meeting (BusinessGreen 2009). This position is supported by the emerging economies of China and India. BusinessGreen also reported that the African call for increased funding to Africa is consistent with earlier calls by British Prime Minister, Gordon Brown, for developed nations to agree to provide $\$ 100$ billion in CC funding to developing countries, as part of any Copenhagen deal.

Kofi Annan, the former UN Secretary-General, said recently that 'it is a tragic irony that the countries which have done the least to cause climate change are those which are suffering and will suffer most from its impact'. He called for fairness: 'Climate justice demands that the industrialised countries meet their historic responsibility for the accumulation of greenhouse gases' (Williams 2009). 
The climate control policy regime can be analysed from both the global or national perspective, or from the way in which the two regimes interact. As its name indicates, the United Nations Framework Convention on Climate Change (UNFCCC) of 1992 was intended to be only a framework agreement, dependent on subsequent protocols for implementation. The first set of protocols came in 1997; the Kyoto Protocol (KP) (entered into force on 16 February 2005) currently represents the primary international regulations on CC. The December 2009 Copenhagen summit is intended to reinforce and strengthen current targets and set the course to limit the rise in global temperatures to a maximum of $2^{\circ} \mathrm{C}$ (Williams 2009).

The KP, agreed to by parties to the UNFCCC, is aimed primarily at the issue of escalating levels of GHG in the atmosphere. Developed countries (so-called Annex 1 parties) that are signatories to this agreement legally committed themselves to binding reduction targets. Developing countries that ratified the KP did not assume any binding commitment; according to Article 10 of the KP, they are only required to fulfil general reporting requirements (UN 1997, 9-11). This reflects the principle of 'common but differentiated responsibilities and respective capabilities' duly provided for in the UNFCCC (1992, Article 3). Collectively, developed countries are required to reduce their GHG emissions by an average of 5.2 per cent below the 1990 levels, between the years 2008 and 2012 (Shin 1998, 519; UN 1997, 4). They must meet their targets primarily through national measures. As an additional means, the KP introduced three market-based mechanisms, thereby creating what is now known as the 'carbon market'. ${ }^{2}$

The first of these three market-based mechanisms is the Joint Implementation (JI) mechanism (Article 6). It allows an Annex 1 (developed) country to undertake a project that reduces GHG emissions in another developed country, and then count the resulting emission reductions towards its own national target. JI projects generate Emission Reduction Units (ERU), which can be traded with any other Annex 1 party. The second, the Clean Development Mechanism (CDM) (Article 12) allows developed countries to buy Certified Emissions Reduction (CER) certificates from approved projects in developing countries that have ratified the KP. These credits can be used by the developed country to meet its own reduction target. And finally, there is the Emissions Trading (ET) mechanism (Article 17), which earns the investing country Assigned Amount Units (AAUs).

Given that developing countries do not engage the JI and ET mechanisms (as stipulated by the KP), this article focuses on the CDM, the one KP mechanism applicable to developing countries and Africa. As stated above, the CDM permits developed countries to invest in projects that reduce GHGs in developing countries and earn carbon credits or carbon offsets (UN 1997). Article 12 of the KP spells out the dual aim of CDM: to help developing countries achieve sustainable development while allowing developed countries to meet their stipulated emission reduction targets. The $\mathrm{CDM}$ is subject to the authority and guidance of the Meeting of Parties (MoP) of the UNFCCC, supervised by an executive board. Emission reductions resulting from each 
CDM project are certified by operational entities designated by the MoP on the basis of: '(a) voluntary participation approved by each Party involved; (b) real, measurable, and long-term benefits related to the mitigation of climate change; and (c) reductions in emissions that are additional to any that would occur in the absence of the certified project activity' (UN 1997, 14). Private and/or public entities can be involved under the $\mathrm{CDM}$. Until recently, the only African country with significant involvement in the KP mechanism for GHG emission reduction was South Africa.

However, the CDM process is perceived as unfair to Africa and to other emerging economies. It is seen as biased toward mitigation - the reduction of GHG emissions (which benefits developed countries in meeting legal targets) and does little on adaptation, assisting developing countries that are particularly vulnerable to the adverse effects of climate change in meeting the costs of adaptation (KP 1997, Article 128). As noted earlier, Africa estimates that $\$ 67$ billion will be needed to deal with the effects of CC on a continental scale. At the seventh World Forum on Sustainable Development, Jean Ping, Chairman of the African Union Commission, declared that at the forthcoming climate conference in Copenhagen, 'Africans will speak with one voice' and will demand that 'reparations and damages be paid by polluting countries' (Jerichow 2009).

In addition to the UNFCCC and the KP, a number of other significant documents on $\mathrm{CC}$ have been published, notably by the IPCC. The reader is directed to these documents, as a detailed discussion falls outside the scope of this article. These publications have contributed towards a holistic understanding of CC, and among them can be listed the following: the IPCC Assessment Report series for 1990, 1995, 2001 and 2007 from Working Groups I-III that consider the physical science basis of climate change; climate change impacts, adaptation and vulnerability, and mitigation (IPCC 2009); The Stern Review Report on the Economics of Climate Change (Stern 2006); and the book (and film) 'An inconvenient truth: A global warning' (Gore 2006).

\section{National climate change regulatory regimes}

Laws and policies regulating $\mathrm{CC}$ have mushroomed in key destination countries for African exports. A summary of some key national CC policy regimes from Europe and the US is presented in Table 1.

Some developed countries have introduced, in their national law, the principle of carbon tariffs - a penalty imposed on imported products with a high carbon footprint. Although such tariffs are, to a great extent, aimed at emerging economies like those of the G5 nations which are still heavily dependent on coal for more than 65 per cent of their total energy, the least developed countries will also suffer economic strains (Sneddon 2009, 5). The US, for example, passed the Clean Energy and Security Act in June 2009, which permits the government of the US to take action against any trading partner that fails to meet its GHG standards - the act enters into force in 2025 (Cambell 2009, 15). Similar initiatives have gained momentum in the European Union (EU) and Canada. The objective of such measures is to mitigate against a competitive disadvantage that industries in the more developed countries face vis-à-vis industries in least developed countries not constrained by $\mathrm{CC}$ regulations. 
Table 1: Selected national and regional CC policy regimes

\begin{tabular}{|c|c|}
\hline Country & CC policy and legislation \\
\hline European Union & $\begin{array}{l}\text { - 2005: The EU - Emissions Trading System (EU-ETS) } \\
\text { - 2006: Initiative on Food Miles and Organic Certification } \\
\text { - 2008: December: EU Green Stimulus Package } \\
\text { - 2009: The EU Directive on Renewable Energies } \\
\text { - 2009: A target of a } 20 \text { per cent reduction in GHG emissions by } 2020\end{array}$ \\
\hline United Kingdom & $\begin{array}{l}\text { - 2006: UK CC Programme } \\
\text { - 2006: Initiative on Food Miles and Organic Certification } \\
\text { - 2008: UK Energy White Paper } \\
\text { - 2008: Climate Change Act } \\
\text { - 2008: Motor Scrappage Scheme } \\
\text { - 2009: Carbon Budget } \\
\text { - 2009: Project 10:10 - UK businesses and other sectors to work } \\
\text { towards reducing emissions by } 10 \text { per cent by } 2010\end{array}$ \\
\hline United States & $\begin{array}{l}\text { - 2008: Change in rear guard and change in CC policy } \\
\text { - 2009: Clean Energy and Security Act } \\
\text { - 2009: Climate Bill } \\
\text { - 2009: Electric Car Fund } \\
\text { - 2009: Motor Scrappage Scheme - } 316189 \text { cars turned in worth } \\
\text { US\$ 1.326 million in two weeks } \\
\text { - 2009: Record Proxy season see } 68 \text { CC-related shareholder resolutions } \\
\text { filed with a } 50 \text { per cent success rate }\end{array}$ \\
\hline
\end{tabular}

\section{Africa's key export destinations}

This section of the article presents results from an analysis of UNCTAD data on Africa's key export destinations. For the most part, Africa's principal international trading partners continue to be its former colonisers and/or slave masters, i.e. Europe and the US. Critical emerging markets like China and India have been opening up, but these new trade arrangements have not yet matured. A number of trade agreements also exist among African countries and their various regional groupings. Those of high significance include:

- Economic Partnership Agreements (EPAs): made possible through the Cotonou Agreement of 2000 that put in place a new framework for cooperation over trade and aid between the EU and 78 members of African Caribbean and the Pacific (ACP) Region. Free trade areas are being established between the EU and each of the key regional groupings that include the Common Market for Eastern and Southern Africa (COMESA); Southern African Development Community (SADC); Economic Community of Central African States (CEMAC); and Economic Commission of West African States (ECOWAS) for the African continent. The EPAs are viewed as promoting reciprocal free trade arrangements in line with WTO requirements. The EPAs are supposed to have holistic frameworks covering trade and related aspects, among others 'trade in goods and services, investment, competition, trade 
facilitation, and Aid for Trade'(UNCTAD 2009, 12). The Cotonou Agreement makes provisions for differentiating least developed countries (LDCs) and non-LDCs;

- South Africa Free Trade Area (FTA) with the EU concluded in October 1999;

- Trade, Investment and Development Cooperation Agreement (TIDCA) between Southern African Customs Union (SACU) and the United States, concluded in 2008;

- The African Growth and Opportunity Act (AGOA) which was concluded in 2000 to offer tangible incentives for African countries to continue their efforts to open their economies and build free markets; and

- The United States Trade and Investment Framework Agreement (TIFA). The USA has concluded an array of these TIFAs with Algeria, Tunisia, Nigeria, Ghana and South Africa as well as regional groupings including two Regional Economic Communities (RECs), The West African Economic and Monetary Union (UEMOA) and Common Market for East and Southern Africa (COMESA). The trade agreements and arrangements have a strong bearing on exports. (see UNCTAD 2009, 8-13)

Table 2, in conjunction with Figures 1-4, gives an overview of the leading export destinations for African goods, as well as the percentage of national exports sent to these destinations by each country between the years 2004 and 2006. The 52 African countries are ranked in descending order, as determined by percentage of exports. The ranked countries are divided into three groups, namely: (1) upper, representing the African countries with the highest imports to the corresponding destination; (2) middle, those countries that follow; and (3) lower groups, those countries with the lowest trade percentages with the corresponding destination. This grouping allows the reader to see exactly which African countries stand to be most affected by CC regulatory regimes that are likely to impinge on international trade. Although not discussed in this article, at the periphery of this argument is how South Africa is likely to relate to its other African trade partners as it faces pressure from Europe and the US to address CC. 
Table 2: Overview of export destinations (2004-2006)

\begin{tabular}{|c|c|c|c|}
\hline \multirow{2}{*}{$\begin{array}{l}\text { Key export } \\
\text { destination }\end{array}$} & \multicolumn{3}{|c|}{ Countries in groups ranked from top to bottom $(\mathrm{N}=52)$} \\
\hline & Upper Group $(n=17)$ & Middle Group $(\mathrm{n}=18)$ & Lower Group $(n=17)$ \\
\hline $\begin{array}{l}\text { Developed } \\
\text { Europe }\end{array}$ & $\begin{array}{l}\text { Sao Tome and Principe, } \\
\text { Botswana, Libyan, } \\
\text { Central African } \\
\text { Republic, Morocco, } \\
\text { Tunisia, Gambia, } \\
\text { Liberia, Mauritius, } \\
\text { Cameroon, Burundi, } \\
\text { Mauritania, Cape } \\
\text { Verde, Seychelles, } \\
\text { Sierra Leone, } \\
\text { Madagascar and Algeria }\end{array}$ & $\begin{array}{l}\text { DRC, Niger, Guinea, } \\
\text { Rwanda, Mozambique, } \\
\text { Côte d'Ivoire, Zambia, } \\
\text { Tanzania, Namibia, } \\
\text { Malawi, Ghana, } \\
\text { Ethiopia, South, Africa, } \\
\text { Uganda, Eritrea, Egypt, } \\
\text { Equatorial Guinea and } \\
\text { Kenya }\end{array}$ & $\begin{array}{l}\text { Senegal, Nigeria, } \\
\text { Zimbabwe, Mali, } \\
\text { Gabon, Togo, Benin, } \\
\text { Burkina, Faso, Angola, } \\
\text { Lesotho, Chad, } \\
\text { Congo, Djibouti, } \\
\text { Sudan, Guinea-Bissau, } \\
\text { Somalia and Swaziland }\end{array}$ \\
\hline US & $\begin{array}{l}\text { Chad, Lesotho, Gabon, } \\
\text { Nigeria, Angola, Congo, } \\
\text { Equatorial Guinea, } \\
\text { Algeria, Madagascar, } \\
\text { Ghana, South Africa, } \\
\text { Côte d'Ivoire, DRC, } \\
\text { Mauritius, Malawi, } \\
\text { Sierra Leone and Egypt }\end{array}$ & $\begin{array}{l}\text { Guinea, Liberia, } \\
\text { Guinea-Bissau, Namibia, } \\
\text { Cameroon, Kenya, } \\
\text { Swaziland, Ethiopia, } \\
\text { Libyan, Cape Verde, } \\
\text { Zimbabwe, Morocco, } \\
\text { Rwanda, Niger, } \\
\text { Botswana, Uganda, } \\
\text { Eritrea and Tanzania }\end{array}$ & $\begin{array}{l}\text { Mozambique, Gambia, } \\
\text { Djibouti, Tunisia, } \\
\text { Senegal, Zambia, } \\
\text { Togo, Seychelles, } \\
\text { Burkina Faso, Somalia, } \\
\text { Mali, Burundi, Central } \\
\text { African Republic, } \\
\text { Sudan, Benin, } \\
\text { Mauritania, and Sao } \\
\text { Tome and Principe }\end{array}$ \\
\hline $\begin{array}{l}\text { Combined, } \\
\text { Europe and } \\
\text { US }\end{array}$ & $\begin{array}{l}\text { Sao Tome and Principe, } \\
\text { Libyan, Botswana, } \\
\text { Chad, Lesotho, Algeria, } \\
\text { Liberia, Morocco, } \\
\text { Madagascar, Mauritius, } \\
\text { Gabon, Central African } \\
\text { Republic, Gambia, } \\
\text { Tunisia, Cameroon, } \\
\text { Nigeria and Sierra } \\
\text { Leone }\end{array}$ & $\begin{array}{l}\text { Burundi, Cape Verde, } \\
\text { DRC, Mauritania, } \\
\text { Seychelles, Côte } \\
\text { d'Ivoire, Ghana, Guinea, } \\
\text { Equatorial Guinea, Niger } \\
\text { Rwanda, Malawi, } \\
\text { Namibia, South Africa, } \\
\text { Angola, Mozambique, } \\
\text { Zambia and Tanzania }\end{array}$ & $\begin{array}{l}\text { Ethiopia, Egypt, } \\
\text { Uganda, Congo, } \\
\text { Eritrea, Kenya, } \\
\text { Senegal, Zimbabwe, } \\
\text { Mali, Togo, Benin, } \\
\text { Burkina Faso, Guinea- } \\
\text { Bissau, Swaziland, } \\
\text { Djibouti, Sudan and } \\
\text { Somalia }\end{array}$ \\
\hline Africa & $\begin{array}{l}\text { Swaziland, Djibouti, } \\
\text { Mali, Zimbabwe, } \\
\text { Kenya, Senegal, } \\
\text { Malawi, Namibia, } \\
\text { Uganda, Zambia, } \\
\text { Burkina Faso, Niger, } \\
\text { Rwanda, Cape Verde, } \\
\text { Côte d'Ivoire, Togo and } \\
\text { Benin }\end{array}$ & $\begin{array}{l}\text { Ghana, United Rep. } \\
\text { of Tanzania, Gambia, } \\
\text { Eritrea, } \\
\text { Lesotho, Mozambique, } \\
\text { Guinea-Bissau, Ethiopia, } \\
\text { South Africa, Burundi, } \\
\text { Botswana, Cameroon, } \\
\text { Central African } \\
\text { Republic, Mauritius, } \\
\text { Nigeria, Tunisia, DRC } \\
\text { and Sao Tome and } \\
\text { Principe }\end{array}$ & $\begin{array}{l}\text { Mauritania, Egypt } \\
\text { Gabon, Liberia } \\
\text { Madagascar, Morocco, } \\
\text { Somalia, Sierra } \\
\text { Leone, Guinea, } \\
\text { Libyan, Algeria, } \\
\text { Sudan, Congo, Angola, } \\
\text { Seychelles, Equatorial } \\
\text { Guinea and Chad }\end{array}$ \\
\hline
\end{tabular}




\section{Exports to Europe}

The ten countries with the highest national exports to Europe are Sao Tome and Principe, Botswana, Libya, Central African Republic, Morocco, Tunisia, Gambia, Liberia, Mauritius and Cameroon (Figure 1). Sao Tome and Principe is ranked first, with exports to Europe amounting to 88.56 per cent of its total exports. Based on data from UNCTAD, the remaining smaller percentages were split among the US; eastern, southern and south-eastern Asia; western Asia and Africa. Cameroon ranked tenth, with total exports to Europe pegged at 66.5 per cent.

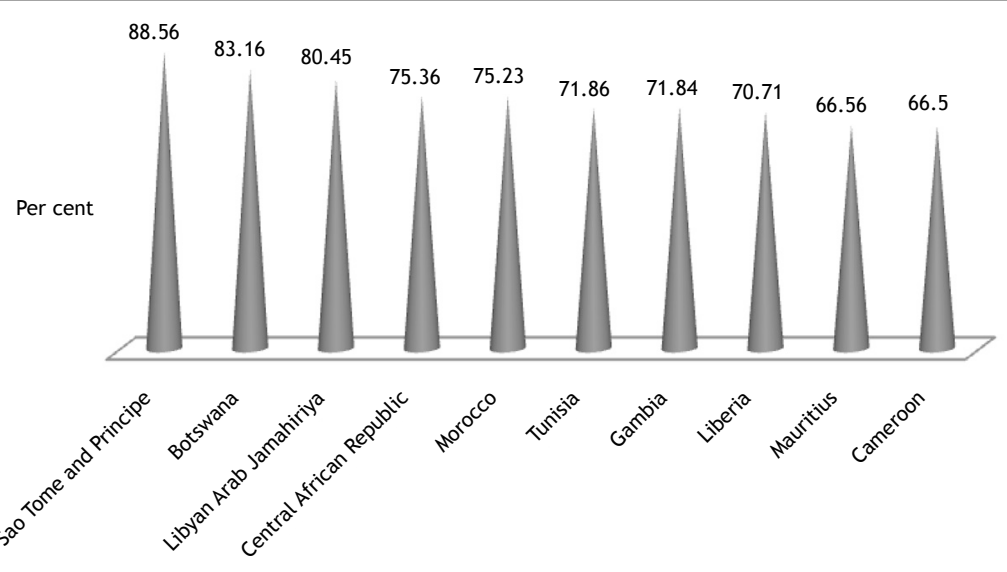

Figure 1: Top ten exporters to Europe (2004-2006)

\section{Exports to the US}

The ten countries with the highest national exports to the US are Chad, Lesotho, Gabon, Nigeria, Angola, Congo, Equatorial Guinea, Algeria, Madagascar and Ghana (Figure 2). Chad, Lesotho, Gabon each exports $73.14,70.5$ and 59.48 per cent of their total exports respectively. On the other hand, Algeria, Madagascar and Ghana, in the $8^{\text {th }}, 9^{\text {th }}$ and $10^{\text {th }}$ positions, export $24.89,23.04$ and 18.66 per cent respectively; South Africa is ranked $11^{\text {th }}$ with its total export to the US standing at 11.2 per cent. The bottom ten countries in terms of the US export market include the Seychelles, Burkina Faso, Somalia, Mali, Burundi, Central African Republic, Sudan, Benin, Mauritania, and Sao Tome and Principe. The Seychelles' exports stand at 0.32 per cent, while Sao Tome and Principe's share is 0 per cent. The bottom ten countries are not likely to be heavily impacted by the changing $\mathrm{CC}$ compliance regimes in the US. 


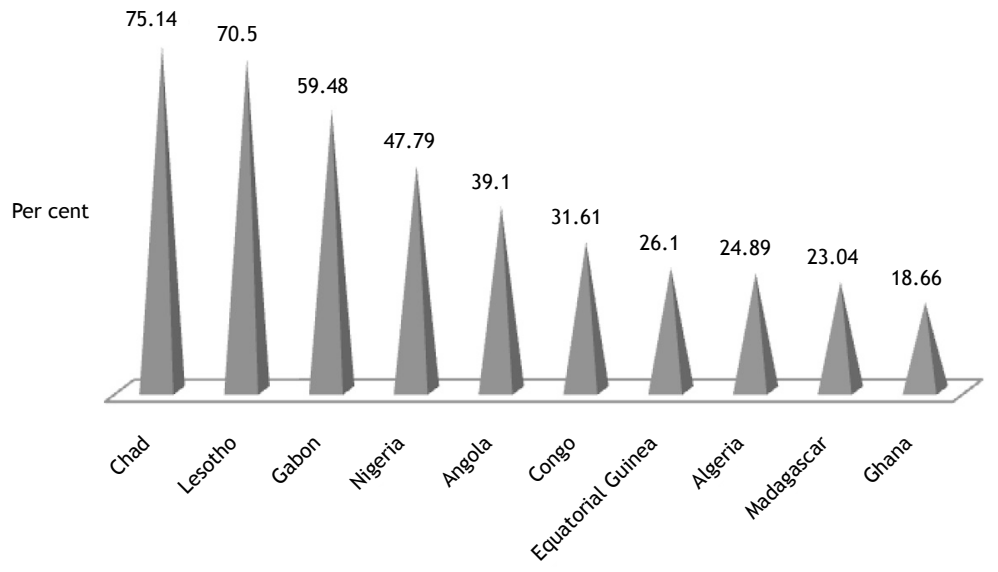

Figure 2: Top ten exporters to the US (2004-2006)

\section{Combined exports to Europe and the US}

In order to have a clearer picture and further insights regarding Africa's exports to the top two global destinations (Europe and the US) a calculation was made based on combined figures. The picture that emerged was of value. The ten countries exporting the most to both Europe and the US are Sao Tome and Principe, Libya, Botswana, Chad, Lesotho, Algeria, Liberia, Morocco, Madagascar and Mauritius (Figure 3). Sao Tome and Principe, Libya and Botswana each exports $88.56,85.34$ and 85.07 per cent of their totals respectively. The key export commodities are cocoa (and most recently oil) for Sao Tome and Principe, oil for Libya as well as diamonds and beef for Botswana.

On the other hand, Morocco, Madagascar and Mauritius, in the $8^{\text {th }}, 9^{\text {th }}$ and $10^{\text {th }}$ positions, export $77.95,77.51$ and 77.37 per cent - in that order. Surprisingly, South Africa is at a distant $31^{\text {st }}$ position, but with a fairly high figure of 50.18 per cent of its trade finding its way to the said destinations. South Africa's trade volume is interesting to note, as the country is widely perceived (by itself and the international community) as Africa's growth pole and the engine for propelling overall economic growth in Africa.

The ten countries with the least exports to Europe and the US include Zimbabwe, Mali, Togo, Benin, Burkina Faso, Guinea-Bissau, Swaziland, Djibouti, Sudan and Somalia. Zimbabwe, which comes $43^{\text {rd }}$ in the continent's ranking, exports a combined 25.82 per cent while Somalia, ranked last, exports a mere 1.7 per cent. Three countries from this bottom ten group share this common feature: highly mediasised political instability: Sudan's president is the subject of an arrest warrant issued by the International Criminal Court; Somalia has been without a real government for almost two decades; while Zimbabwe has just emerged from political turmoil following a disputed presidential ballot in March 2008 and the subsequent conclusion of a global political agreement to share power among the three main political parties in September 2008. 


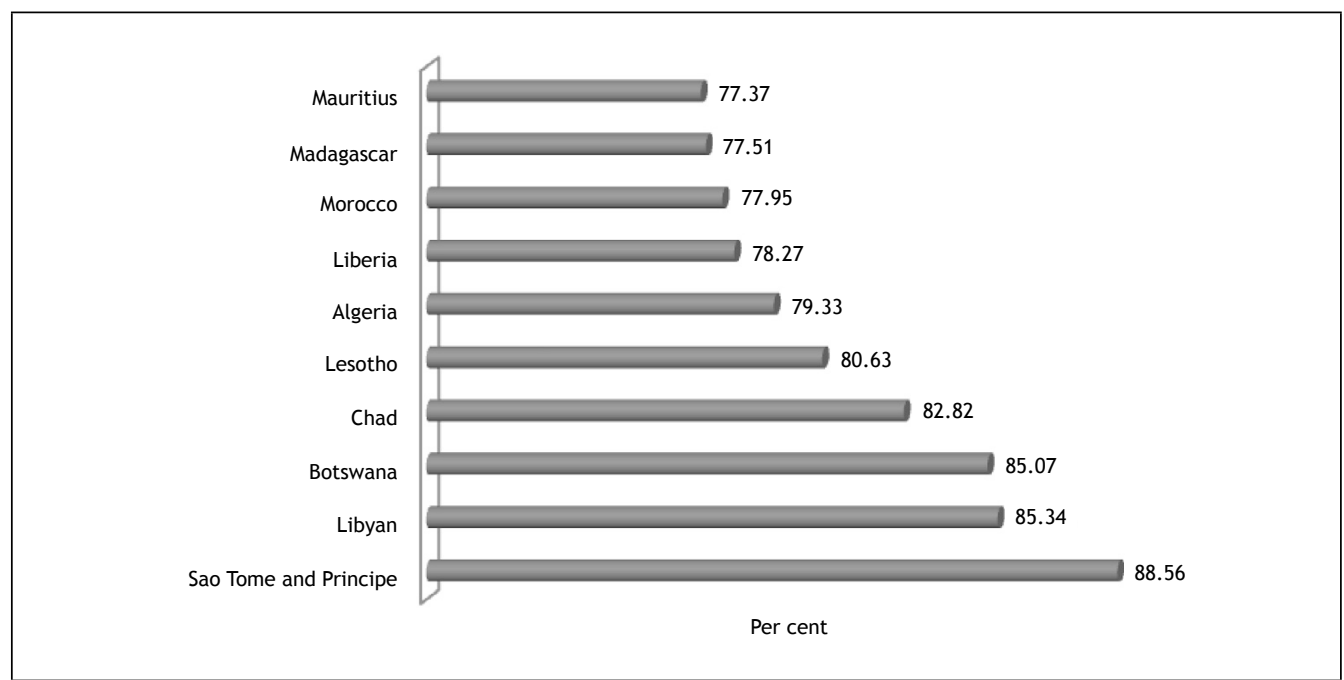

Figure 3: Top ten exporters to Europe and the US (2004-2006)

\section{The oil-exporting countries analysis}

Oil remains one of the key export products of close to half the countries of Africa - 19 to date, with a high probability that major discoveries will be made in the near future. Given that fossil fuels fuel GHG emissions both in the process of extraction and in their use, this sector remains the key target for strong CC compliance regulations. Another special concern regarding this export is that many (if not most) countries endowed with fossil fuel depend on it - nearly exclusively - as the country's sole source of foreign capital. Any CC regulatory regime from key export destinations will, therefore, have severe negative impacts on the exporting African countries.

Four of the 19 African oil exporting countries, namely Algeria, Chad, Libya and Sao Tome and Principe, feature among the top ten exporters to Europe and the US. The 19 are ranked in Figure 4. Algeria and Libya are also members of the Organisation of Petroleum Exporting Countries, OPEC. Oil is the greatest export product for Sao Tome and Principe, Libya and Chad, which respectively rank $1^{\text {st }}, 2^{\text {nd }}$ and $3^{\text {rd. }}$. With the struggle against 'dirty' fossil fuels intensifying in Europe and US, oil-exporting countries will likely face difficult times ahead. The impending advent of the electric car is one challenge; stepped-up off-shore oil drilling in the US, aimed at shortening the supply chain and minimising the carbon footprint, is another great challenge. 


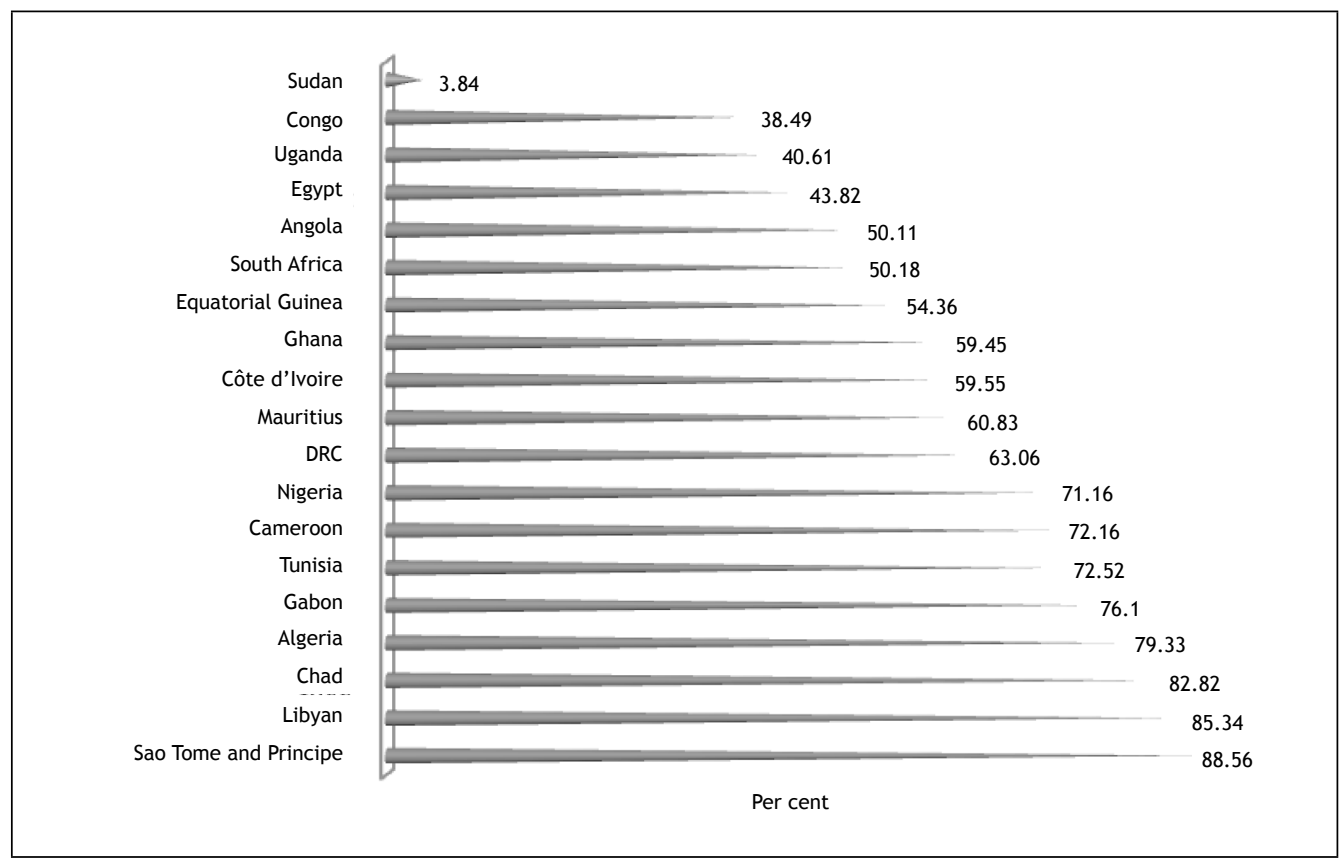

Figure 4: The 19 oil-exporting countries (2004-2006)

The interest and growth in biofuels also offers fossil fuel-producing countries competition, notably from Latin America. It is a controversial technology, critiqued by those who see the transformation of maize (corn), a food crop, into an energy crop, as a step backward in assuring global food security. Some argue that corn stocks normally reserved by countries from North America and Europe for relief purposes in Africa are now being used as feedstock for biofuels, resulting in decreased quantities of grain finding their way into the African import market and driving up prices. Indeed, in the most recent Global Hunger Index developed by the International Food Policy Research Institute (INFPRI), biofuels and climate change are cited as 'introducing drastic changes to food consumption, production, and markets' (IFPRI 2009). While the biofuels and food (in)security debate is still raging in Africa, South Africa finalised its Biofuels and the Biofuels Industry Strategy in 2008 (DEAT 2008). However, a planned maize stock feed biofuels project was recently suspended while the use of jatropha as feedstock is also on hold, pending intensive investigation into the plant's alleged high water intake. 


\section{Intra-African trade (South-South trade)}

The story of the African Renaissance and CC cannot be completed without the active promotion and expansion of intra-African trade. Swaziland, Djibouti, Mali, Zimbabwe, Kenya, Senegal, Malawi, Namibia, Uganda and Zambia emerged as the top ten countries whose goods were primarily Africa-bound (Figure 5). Of course a number of reasons could be cited, chief among them trade barriers imposed by the West on the claim of poor governance; case in point is a country like Zimbabwe. Whatever the reasons, it is always an element of good governance to produce for the local African market. In fact, this should be Africa's key bargaining chip when the new climate deal is negotiated. Shorter supply chains mean reduced GHG emissions. Governments and companies will certainly need to open up new regionalised and national markets in order to be selfreliant and carbon-compliant.

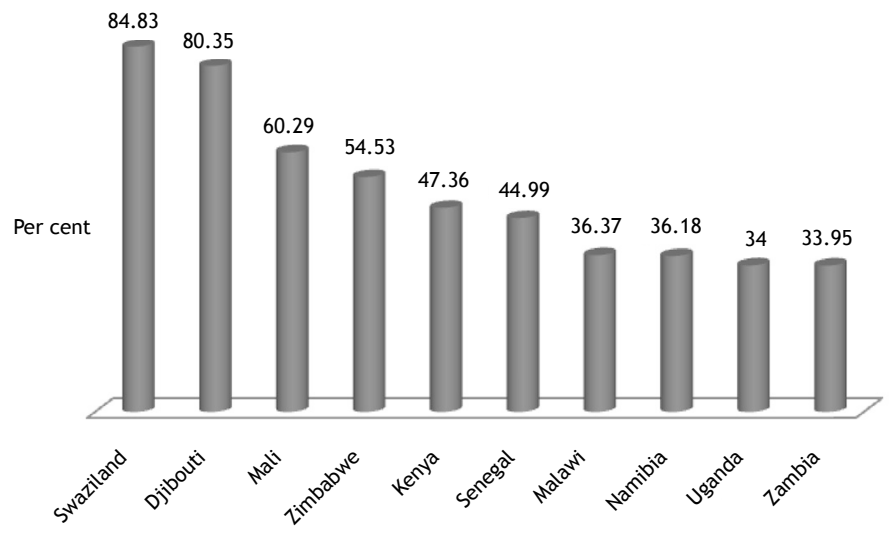

Figure 5: Top ten African exporters to African destinations (2004-2006)

Swaziland, Djibouti and Mali each exported 84.83, 80.35 and 60.29 per cent of their total export base within Africa. Those countries at the bottom of the $\log$ (ranked $43^{\text {rd }}$ to $52^{\text {nd }}$ ) include Sierra Leone, Guinea, Libya, Algeria, Sudan, Congo, Angola, Seychelles, Equatorial Guinea and Chad. Ironically, seven of these countries are oil exporters, while the continent spends huge amounts of its limited resources importing oil from the Middle East and beyond.

Clearly, Africa's preferred export destinations for 2004-2006 was developed Europe and the US. This trend will continue for decades to come. If African governments are unable to meet increasingly stringent $\mathrm{CC}$ regulatory regimes emanating from these regions, the impact on the continent's trade will be devastating. Developing African trade destinations is key. 


\section{Implications of CC for African trade and development}

Cosbey $(2009,86)$ maintains that there is consensus that trade serves as an important engine of economic growth, and through such growth, development. Hence the need to pay particular attention to a global development phenomenon, such as $\mathrm{CC}$, that is transforming trade's potential for development. There are two types of impacts: those arising from climate change itself, and those from $\mathrm{CC}$ legislation and institutions. They are both direct and indirect as well as negative and positive, although overall, negative impacts outweigh the positive (ibid.). A detailed account of the impacts is presented in Table 3. From Cosbey's observations $(2009,95)$ the most significant CC impacts on trade are the following:

- Shifts in traditional patterns of international trade, a product of climate change impacts on natural resource-based production, and of climate change policies that will punish GHG-intensive goods and methods of production;

- Uneven burden of those shifts, falling most heavily on developing country producers and exporters that are at once harder hit by impacts and less capable of anticipating and responding to those impacts;

- Probable increase in the costs of transport, due to climate change policies and the impacts of climate change on coastal transportation infrastructure.

Table 3: The impact of climate change on trade potential

\begin{tabular}{|l|l|l|}
\hline CC impact & Possible linkages & Examples \\
\hline \multirow{2}{*}{$\begin{array}{l}\text { Direct impact } \\
\text { of the changing } \\
\text { climate }\end{array}$} & $\begin{array}{l}\text { Changes in traditional patterns } \\
\text { of global trade }\end{array}$ & $\begin{array}{l}\text { Tropical export-oriented agriculture } \\
\text { less viable due to weather pattern } \\
\text { disruptions }\end{array}$ \\
\cline { 2 - 3 } & $\begin{array}{l}\text { Increased costs of trade, result } \\
\text { infrastructure }\end{array}$ & $\begin{array}{l}\text { Port facilities damaged, shifted } \\
\text { in response to sea-level rise and } \\
\text { increasing storm activity }\end{array}$ \\
\cline { 2 - 3 } & $\begin{array}{l}\text { Decreased costs of trade, result } \\
\text { of climate-related impacts }\end{array}$ & $\begin{array}{l}\text { Opening up of the North-West } \\
\text { Passage through the Arctic }\end{array}$ \\
\hline \multirow{2}{*}{$\begin{array}{l}\text { Direct impact } \\
\text { of CC policy } \\
\text { regimes }\end{array}$} & $\begin{array}{l}\text { Mitigation policies increase the } \\
\text { cost of transportation-related } \\
\text { fuel, increasing costs of trade }\end{array}$ & $\begin{array}{l}\text { GHG-intensive transport modes such } \\
\text { as air freight would be hardest hit }\end{array}$ \\
\cline { 2 - 3 } & $\begin{array}{l}\text { Changes in traditional patterns } \\
\text { of global trade }\end{array}$ & $\begin{array}{l}\text { Carbon taxes increase costs of fuel } \\
\text { and electricity used in production. } \\
\text { Renewable mandates create new } \\
\text { markets for low-GHG energy } \\
\text { technologies and products }\end{array}$ \\
\hline
\end{tabular}




\begin{tabular}{|l|l|l|}
\hline Indirect impact & $\begin{array}{l}\text { The need to address adaptation } \\
\text { draws resources away from } \\
\text { investing in prequisites to gain } \\
\text { from trade }\end{array}$ & $\begin{array}{l}\text { Underinvestment in trade } \\
\text { facilitation, transportation } \\
\text { infrastructure, investment } \\
\text { promotion }\end{array}$ \\
\cline { 2 - 3 } & $\begin{array}{l}\text { International climate-related } \\
\text { assistance fosters more } \\
\text { competitive exporters }\end{array}$ & $\begin{array}{l}\text { Assistance to improve energy } \\
\text { efficiency, promote new energy } \\
\text { sources that offer greater reliability } \\
\text { of supply }\end{array}$ \\
\hline
\end{tabular}

Source: Cosbey $(2009,88)$

A recent briefing by the International Trade Centre (ITC) indicates that the UK organic fresh produce market is worth about $£ 42$ million (ITC $2009,1-2$ ), with a small but growing proportion of this market coming from Africa via airfreight. At the international level, leading countries using airfreight for exports include Egypt, Kenya, Morocco, the US, Zambia and, to a significant extent, South Africa, Cameroon, Gambia and Ghana (ibid.). Just as the trade is responsible for job creation in the UK, it equally supports the livelihoods of thousands, if not millions, of farmers and farm workers in Africa, of which the majority are women. However, the use of airfreight in this trade has prompted a backlash from consumers and other green organisations battling to establish (with a view to reducing) the carbon footprint associated with the organic fresh produce trade. This recent campaign, dubbed 'food miles', is fuelled by consumer activism and threatens the livelihoods of those involved in the trade. It is proving successful. A number of organic certifiers in Europe have withdrawn organic certification to air-freighted products, because of their high carbon footprint. The EU Environment Commissioner, Stavros Dimas, strongly encourages this kind of activism:

The battle against climate change must be fought on all fronts and everyone must contribute. It is not only the remit of companies and governments; consumers also have their part to play. By purchasing environmentally and climate-friendly products individual customers send the right signal to producers who respond in turn by producing more eco-friendly products. (Sida 2009, 12)

\section{International trade issues in global climate policy regime: Wrong turn from Rio}

At the Earth Summit held in Rio de Janeiro in 1992, attending governments signed the UNFCCC, whose key objective was 'stabilization of greenhouse gas concentrations in the atmosphere at a level that would prevent dangerous anthropogenic interference with the climate system'. Developed countries agreed to return their emissions to 1990 levels (UNFCCC 1992). The UNFCCC did not deliberate on trade in the context of CC, more particularly trade with Africa. A tepid reference to trade features once in Article 3: 'Measures taken to combat climate change, including unilateral ones, should not constitute a means of arbitrary or unjustifiable discrimination or a disguised restriction 
on international trade' (UNFCCC 1992, 2). Five years on, the KP does not offer much more of a protective guideline on trade, leaving developed countries with enough wiggleroom to be abusive. Articles 3.14 and 2.3 of the KP stipulate:

[E]ach Party included in Annex I shall strive to implement (its GHG mitigation commitments) in such a way as to minimize adverse social, environmental and economic impacts on developing country Parties ... The Annex I parties shall strive to implement policies and measures under Article 2.3 in such a way as to minimise adverse effects, including the adverse effects of climate change, effects on international trade, and social, environmental and economic impacts on other Parties, especially developing countries. (Cosbey 2009, 96)

In 1992 many people in both the business and political fraternity were still sceptical about $\mathrm{CC}$ and its potential repercussion for the environment, so the limited reference to trade in the UNFCCC is understandable. (It could also have been a kept deliberately vague to permit buy-in from warring parties around the $\mathrm{CC}$ debate.) The follow-up clauses in Articles 2.3 and 3.14 of the KP, however, were not very helpful. The power gradient still favours developed countries wanting to do business with developing nations. In the absence of clearer and stricter guidelines to indeed 'minimise adverse effects ... on international trade ... especially in developing countries ...' as advocated in the $\mathrm{KP}$, developing countries will suffer. Developed countries are increasingly insisting that developing countries share the burden of CC, in a way that is unfair. India's Minister for Environment and Forests has already threatened to 'walk out' of the Copenhagen summit if 'any kind of legally binding agreement on emissions trajectory' were imposed on developing countries (LPAC 2009). This position of 'shared' responsibility was at the root of the refusal of the US, Australia, Canada and New Zealand to be parties to the KP (Nhamo 2006, 167-176). Australia only ratified the KP after a change of political leadership in 2008, and the US has shown strong signs of cooperating with the international community since Barack Obama took office in January 2009.

Climate change is being used as a weapon to curtail international trade, especially from regions like Africa presumed to be hostile to transition to low-carbon or carbon neutral positions. It is being used to strong-arm African governments opposed to the dicta of former colonial powers through selective developmental aid funding, particularly clean technology funding. The CC discourse is being used to protect European markets facing stiff competition from African products such as wine and fresh produce. The French and Spanish wine industries will benefit from consumer activism and political debates surrounding food miles, while international trade in these and other affected products will hurt Africa.

As a sustained and well-financed global movement to replace second-generation carbon-intensive technologies with third-generation organic-based technologies grows in the industrialised North, so too does the likelihood that these second-generation technologies will find their way to Africa. African governments have long complained about the continent being used as a dumping ground for unwanted and obsolete development technologies and even food handouts from the North - from Japanese 
second-hand cars, to mining machinery, computers, feeding milk, to banned pesticides, leaded gasoline, asbestos and other products restricted in the North. This is fact, not the ravings of conspiracy theorists. In the now infamous 12 October 1991 World Bank internal memorandum from Lawrence Summer (then the bank's chief economist, now a US White House economic advisor), the World Bank functionary wrote:

Just between you and me, shouldn't the World Bank be encouraging more migration of the dirty industries to the LDCs (least developed countries)? I can think of 3 reasons (1) I think the economic logic behind dumping a load of toxic waste in the lowest wage country is impeccable and we should face up to that ...

This calculated move by the West to replace second-generation technologies hinges on continued dominance over Africa, the perpetuation of intergenerational poverty, the dependence of African governments, and the need for the West to overcome its own dependence on oil-exporting nations, many of which are African.

The imposition of second-generation technologies on Africa will have a significant bearing on Africa's international trade, as these carbon-intensive technologies will result in huge carbon footprints on goods and services rendered by African countries. At best, this will mean even stiffer competition from environmentally friendly products or greater carbon tariffs; at worst, the outright rejection of African goods and services.

\section{Policy perspectives: Whereto from here?}

Africa's survival in this CC-compliant epoch rests on opening trade routes within its boundaries as it moves towards a single AU authority; increasing trade with other developing countries; developing clean technologies; and becoming full-fledged partners in CC discourse.

Buy local and import greening: the time has come for African governments to seriously consider expanding both the national and intra-regional markets. In this way we reduce our carbon footprint as well as our high dependency on dirty imports. In as much as it will be difficult to curtail the flood of imported goods from key import sources from the North (the US and developed Europe), African governments must put in place import greening regulatory regimes. Apart from the US and Europe, China and India have also become key development and trade partners of Africa, and these countries too need to adhere to the continent's import greening regulatory regimes proposed here. This approach will succeed if the AU agrees to a continent-wide import greening regulatory regime. 'Buy local and import greening' implies challenging ourselves to review trade agreements and barriers that require us to export raw material in perpetuity.

Forest resources a huge plus for Africa: the Payment for Environmental Services (PES) system has gained significant momentum. The PES system presents an opportunity for landowners and those involved in conservation activities to be compensated (CIFOR $2005,1)$. The fundamental thinking is that those involved in providing environmental services should be paid for such (WWF 2006, 2). PES schemes include carbon-sink functions, hydrological protection, biodiversity and landscape aesthetic and/or eco- 
tourism (CIFOR 2005). Large government-driven PES programmes exist in countries like Australia, Brazil, China, Colombia, Costa Rica, the US and the EU. These forest services are not currently realised under the KP arrangements, and African governments need to lobby strongly for their inclusion in the proposed new climate deal. Collectively, a position must be taken to assess how much sink the African forests are providing. Stronger legislation curbing logging and other destructive activities could then be put in place to permit continued industrial growth and counteract the stringent $\mathrm{CC}$ regulatory regimes from our key export destinations.

Coal resources still need to be exploited: since Africa has huge coal reserves that it uses as a source of energy with known significant GHG emissions, the continent needs to fully embrace clean coal technologies as well as emerging technologies for carbon capture and storage (CCS). The CCS technology allows GHG emissions to be captured at source and stored underground in suitable geological formations.

Significant debt relief as a goodwill gesture: African countries are heavily indebted and as part of a goodwill gesture on CC issues and development, developed nations especially the G8 - should offer significant debt relief and, where necessary, increase aid.

Need to consider climate change and development linkages as open question: due to the complexity surrounding climate change and development and other related key factors, Africa must always consider the discourses and unfolding events as an open question to which some answers will only become clearer in the future.

Three Cs: the notions of coherence, collaboration and coordination are critical points that will assist African governments as they look ahead in terms of the post-KP phase. Collaboration in particular means the need to be partners in addressing $\mathrm{CC}$, economic growth and development, hence a call for equal partnerships that will deliver 'win-win' and/or 'lose-lose' situations in their true sense. Once again, African governments need to tackle the three Cs with one voice.

Call for good governance: the measures described above are only possible within the parameters of democracy and good governance.

\section{Acknowledgements}

The author thanks Exxaro Resources Limited for sponsoring the Chair in Business and Climate Change run under Unisa's Centre for Corporate Citizenship.

\section{Notes}

1 http://www.wto.org/english/tratop_e/envir_e/climate_impact_e.htm

2 http://unfccc.int/kyoto_protocol/mechanisms/items/1673.php 


\section{[5( ) ( 5 ( $1 \&($}

0

Arckerman, F. 2009. Carbon markets and beyond: The limited role of prices and taxes in climate and development policy. New York: United Nations.

BusinessGreen. 2009. African Union to call for $\$ 67 \mathrm{bn}$ a year in climate funding. http://www. BusinessGreen.com

Cambell, D. 2009. United States climate change and energy policy: An overview and analysis. Facet Analysis 2: 1-32.

Centre for International Forestry Research (CIFOR). 2005. Payments for environmental services: Some nuts and bolts. CIFOR Infobrief 9: 1-4.

ClimateWorks Foundation. 2009. Towards a global climate agreement: Synthesis briefing paper, June. California: Climate Works Foundation.

Cosbey, A. 2009. How will climate change affect trade's potential to foster development? In Rethinking development in a carbon-constrained world: Development cooperation and climate change, ed. E. Palosuo, 86-99. Helsinki: Finland Ministry of Foreign Affairs.

Department of Environmental Affairs and Tourism (DEAT). 2007. Long-term mitigation scenarios - strategic options for South Africa. Pretoria: Department of Environmental

Affairs and Tourism. 2008. Emerging issue paper: Biofuels. Pretoria: Department of Environmental Affair and Tourism.

European Conference of Ministers of Transport. 1993. Transport policy and global warming.

Paris: European Conference of Ministers of Transport.

Food and Agriculture Organisation (FAO). 2008. Climate change adaptation and mitigation:

Challenges and opportunities for food security. Rome: Food and Agricultural Organisation.

Gore, A. 2006. An inconvenient truth: A global warning. London: Bloomsbury Publishing.

Huq, S., H. Reid and L.A. Murray. 2006. Climate change and development links. London: International Institute for Environment and Development.

Intergovernmental Panel on Climate Change (IPCC). 2007. Working Group II contribution to the Intergovernmental Panel on Climate Change, Fourth Assessment Report Climate Change 2007: Climate change impacts, adaptation and vulnerability, summary for policymakers. Geneva: Intergovernmental Panel on Climate Change.

2009. Reports. http://www.ipcc.ch/publications_and_data/publications_and_data reports.htm\#1

International Food Policy Research Institute. 2009. Press release. New global hunger index: 33 countries have 'alarming' or 'extremely alarming' levels of hunger.

International Trade Centre (ITC). 2009. Trade, climate change and jobs. Geneva: International Trade Centre.

International Union for Conservation of Nature (IUCN). 2004. IUCN's first ever assessment of its greenhouse gas emissions. Brussels: IUCN.

Jerichow, R. 2009. Africa: Let the polluters pay. http://en.cop15.dk/news/ view + news?newsid $=2326$

Kolk, A. and J. Pinkse. 2009. Business and climate change: Key challenges in the face of policy uncertainty and economic recession. Management Online Review 1-9.

LPAC. 2009. India and Africa threaten walk-out at Copenhagen summit. http://www. larouchepac.com/node/11951

Moriguchi, Y. 2006. Establishing a sound material cycle society in Asia. Tokyo: Asia 3R-Conference Secretariat. 
Nhamo, G. 2006. Institutional and legal provisions for the Clean Development Mechanism in South Africa. In Environmental economics and investment assessment, ed. K. Aravossis, 167-176. Southampton: Witpress.

Oxfam. 2007. Adapting to climate change: What's needed in poor countries, and who should pay. London: Oxfam.

Shin, S. 1998. Developing country's perspective on COP3 development (Kyoto Protocol). Energy Policy 26(7): 519-526.

Sneddon, J. 2009. Climate change, agriculture and trade prospects for developing countries. Commonwealth Trade Hot Topics 61: 1-8.

Stern, N. 2006. The Stern review report on the economics of climate change. Warwick: University of Warwick.

Swedish International Development Cooperation Agency (SIDA). 2009. Organic exports - a way to a better life? Export promotion of organic products from Africa. Oslo: Agro Eco BV.

United Nations (UN). 1997. Kyoto Protocol to the United Nations Framework Convention on Climate Char . 2009. World economic and social survey 2009: Promoting development, saving the ptantet. New York: United Nations Secretariat.

United Nations Conference on Trade and Development (UNCTAD). 2009. Economic

Development in Africa Report 2009: Strengthening regional economic integration for Africa's development. Geneva: UNCTAD.

United Nations Framework Convention on Climate Change (UNFCCC). 1992. United Nations

Framework Convention on Climate Change. New York: United Nations Framework Convention on Climate Change Secretariat.

World Resources Institute. 2008. Contribution to global warming: Carbon dioxide emissions from fossil fuel combustion 1900-1999. http://www.wri.org/1-202-729-7600

World Trade Organisation-UNEP. 2009. Trade and climate change. Geneva and Nairobi: WTO-UNEP.

World Wide Fund for Nature (WWF). 2006. Payments for environmental services: An equitable approach for reducing poverty and conserving nature. Gland: World Wide Fund for Nature. 